pÿMediating Global Imaginary : Obama's Address to the Muslim pÿWorld in the Western European press

\title{
Ojala, Markus
}

2011-09-15

pÿOjala , M 2011, ' Mediating Global Imaginary : Obama's Address to the Muslim World in the Western European press ' , Journalism studies , vol. 12 , no. 5 , pp. 673-688 . https://doi.org/10.1080/1461670X.

http://hdl.handle.net/10138/337694

https://doi.org/10.1080/1461670X.2011.587668

acceptedVersion

Downloaded from Helda, University of Helsinki institutional repository.

This is an electronic reprint of the original article.

This reprint may differ from the original in pagination and typographic detail.

Please cite the original version. 


\title{
Mediating Global Imaginary: Obama's “Address to the Muslim World" in the Western European press
}

\author{
Markus Ojala \\ Department of Social Research \\ University of Helsinki \\ markus.ojala@helsinki.fi
}

\begin{abstract}
This article addresses the role of journalism in the construction and mediation of global imaginary. I suggest that the notion of global journalism helps us understand how the image of an interconnected world becomes embedded in the news. The operation of global journalism is illustrated with a qualitative content analysis of the coverage of President Obama's "Address to the Muslim World" in quality British, German and Spanish newspapers. The analysis examines how the newspapers make sense of the President's lecture in Cairo as a transnational news event by evaluating it against the political and historical background of the Middle East conflict and the contentious intercultural relations between "the Muslim world" and "the West". Based on the analysis, I argue that the Western European newspapers craft a strikingly unified narrative of the Cairo event. The article concludes with a discussion on the implications of transnational news narratives and on the relevance of global imaginary in journalism.
\end{abstract}

\section{Keywords}

domestication; globalisation; social imaginary; transnational news event

\section{Introduction}

Globalisation has been a contentious issue in recent debates on journalism. While satellite news networks, international news agencies and the transnational ownership of news media have been interpreted as advancing "a global news arena" (Reese, 2008, p. 241), studies on actual news texts often paint a different picture. Many scholars argue that despite the structural tendencies of globalisation, journalism remains an essentially nationalising social practice; news media make judgements about the newsworthiness of an event on the basis of its geographic, cultural and political proximity (Heikkila" and Kunelius, 2008; Riegert, 2010; Slaatta, 2001). Similarly, while journalists may work in an environment of transnational news flows and mediate common images and concepts, the 
stories they write do not necessarily reflect any awareness of global interconnectedness. Even when reporting on transnational issues, news media tend to promote a sense of national unity: there is a national framing of globally staged events (Biltereyst, 2001; Cottle, 2009; Eide et al., 2008; Roosvall, 2010). Often, these "domestication" practices of the national media are seen as culture-specific differentiations and are regarded as a counterweight to the homogenising tendencies of transnational news agendas. In other words, the globalisation of news is debated within the dialectics of news homogenisation and differentiation (Clausen, 2003, pp. 115; Gurevitch et al., 1993, pp. 2057).

Another way to understand globalisation in journalism is to look beyond the issues of homogenisation and difference and study the construction of globalisation discourses in the news media (e.g. Fairclough, 2006). This suggests that reporting a news event from a national or local angle does not necessarily mean that the connections to transnational and global phenomena are erased. Despite domestication, journalism may express a consciousness of the world as a single place (Berglez, 2008; Hannerz, 2004; Hjarvard, 2001; Robertson, 2005). More specifically, journalism can contribute to a sense of transnational social reality by taking up issues of international relations and transnational phenomena and by demonstrating an understanding of the interrelatedness of regions, problems and processes. Peter Berglez (2008) suggests that "global journalism" may be understood as a particular news style, which is sometimes adopted by journalists when reporting on such issues as climate change, terrorism and epidemics. Global journalism differs from ordinary journalism in its conceptions of space, power and identity: it is a journalistic endeavour that investigates how actions, practices, problems and life conditions in different parts of the world are interrelated.

In this article I examine the idea of global journalism in light of the recent literature on globalisation and social imaginaries. I suggest that interpreting global journalism as the construction of "global imaginary" (Steger, 2009) allows us to understand how journalism contributes to the re-definition of political space and power relations. To explore these ideas empirically I conduct a qualitative content analysis of British, German and Spanish newspaper coverage of President Obama's "Address to the Muslim World". The analysis discusses both the construction of the imaginary of a global reality in journalism and the transnational mediation of such representations. Based on the analysis I suggest that the global imaginary embedded in the studied news narratives is drawn from a particular point of view of global politics and indicates a common Western European interpretation of the news event. I conclude with an assessment of the relevance of global imaginary in journalism.

\section{Global Imaginary in Journalism}

The ubiquitous discourses of globalisation signal perhaps the most significant change in the articulation of political space since the emergence of nationalism. The narratives, myths, rhetoric and ideologies of globalisation change the way social agents make sense of their environment and transform political practices accordingly, thus in effect creating the material reality of global relations (Cameron and Palan, 2004; Fairclough, 2006). Consequently, the political space is being redefined in a way that relativises the position of the nation-state and national cultures and recognises the importance of transnational actors and phenomena. With the strengthening of global consciousness (Albrow, 1996; Robertson, 1992), the global stage has become an ever more important site for the expression of competing ideas, principles and values. According to Manfred Steger (2009), also political ideologies have transformed from the definition of national political projects to the spelling out of universal principles, practices and policies that should regulate global relations. Steger argues that this ideological redefinition manifests a broad transformation in the social imaginary of the past 50 years from the domination of national imagination to what he calls "the rise of the global imaginary". 
For journalism studies, the concept of a social imaginary points to the ways in which journalism functions as a socialising agent by mediating the discourses of social relations. The formation of modern polities as "imagined communities" involves the public construction of particular images of self, community and nation (Anderson, 1991; Schudson, 2003, pp. 689; Steger, 2009, p. 6). The social imaginary of a community is performed in public discourses, and it is through these shared cultural narratives that the polity constructs its collective self-understanding and experience of a common cause (Gaonkar, 2002; Taylor, 2002, p. 106). The claimed rise of the global imaginary calls for an analysis of how contemporary journalism contributes to the possible redefinition of modern polities.

The drawing of connections between local events and transnational processes is by no means foreign to journalism. During the last decade, for instance, stories about financial crises, climate change, war on terrorism, and globalisation itself have been common in the news. All of these phenomena point to interdependencies, shared risks and complex political relations on a transnational scale. Berglez (2008) refers to these aspects of news as global journalism and distinguishes them from the ordinary styles of domestic and foreign news reporting which concentrate only on a single location or event and fail to draw wider connections. This is not to say that journalism has not exhibited an awareness of supranational relations and realities prior to the contemporary discourses of globalisation. What is specific to the current news narratives of global reality, however, is that they contribute to the redefinition of the nation-state as a political space (Cameron and Palan, 2004; Kantola, 2007). Consequently, global journalism should be understood as participating in the construction of a particular social imaginary in which the political space is organised in a non-state-centric manner.

\section{Transnational News Event in Qualitative Analysis}

On 4 June 2009, US president, Barack Obama, gave a lecture at Cairo University in Egypt to a crowd of students, politicians, religious leaders and opposition representatives. The real audience, however, was global as the speech was broadcast live on international and national news networks, translated into 13 languages and distributed via the major social networking sites on the Internet. The speech was dubbed "Obama's Address to the Muslim World" and was perceived as an instance of intercultural dialogue in an attempt to improve America's image, especially in countries with a Muslim majority in Africa, the Middle East and Asia ${ }^{1}$.

A transnational media event, such as President Obama's speech in Cairo, is a conventional way of dealing with global issues for journalism. Such an event focuses the attention of a transnational audience on a particular location, person or issue, which, nevertheless, allows the opening up of a wider panorama of transnational connections (Eide et al., 2008; Hallin and Mancini, 1994). For political leaders, creating media events is a convenient way to direct public attention and promote their agenda (Marshall, 1997). The Cairo event can be seen as a prime example of the way President Obama has repeatedly used his celebrity status to engage in public diplomacy through the media (Kellner, 2010; Redmond, 2010).

Obama's address also marked an important news event for, and was extensively covered in, quality Western European newspapers. The Cairo speech took place within the first six months of Obama's presidency and presented an opportunity for the newspapers to evaluate the impact of the new administration on international politics. After his successful election campaign in 2008 and following the Bush era, Obama was widely seen in Europe as a change-maker in global politics. At the same time, there were open questions about his international political agenda, which made the Cairo address eagerly anticipated. 
Reflecting on the significance of transnational news events in journalism, Elisabeth Eide et al. (2008, p. 13) argue that a global event is not just a foreign event that is viewed from a local perspective. In a global media event, there is more going on than the mere domestication of news into national and local media systems. This article suggests that it is precisely the construction of global imaginary that gives a news event its transnational character. Regardless of the particular national or local viewpoint, a global event is conceived as part of broader spaces, powers and identities. At the same time, however, the coverage of the same event may look different from country to country. The idea of the global imaginary, then, does not assume any transnational homogenisation of news contents. Therefore, the aim of the article is to examine how the interplay between the global event and the domesticating role of the newspaper plays out in a Western European context. Does the national perspective make a difference to the way global relations are imagined in the coverage of the Cairo event? Given the potential plurality of perspectives on global politics, how differently do the Western European quality newspapers report and comment on Obama's address?

The material consists of news coverage of the Cairo event in six Western European newspapers: $A B C$ and El País from Spain, Frankfurter Allgemeine Zeitung and Süddeutsche Zeitung from Germany, and The Independent and The Times from the United Kingdom. I collected the material over a fortnight around the speech, from 28 May to 11 June 2009, and analysed articles from both the print and online versions of the newspapers. ${ }^{2}$ Each paper published 2033 news items, columns, op-eds and editorials on President Obama's speech over the period. In total there were 150 articles included in the analysis, out of which 103 were news items and 47 were columns, editorials or op-eds.

The aim of the qualitative content analysis is two-fold: firstly, to examine how global imaginary is constructed in the newspaper coverage, and secondly, to determine whether the nationality and political leaning of the newspaper shows in the way the social relations in the Cairo event are interpreted. Instead of focusing on individual articles, I analysed the two-week coverage of the speech in each of the newspapers as a whole in order to uncover recurring patterns and form inductive categories (cf. Mayring, 2000; Saukko, 2003, p. 83). I started the analysis by identifying repeating issues, concepts and themes and grouping them together thematically under the categories "main contexts", "problem definitions", "solutions" and "perceived importance of the event" (cf. Altheide, 1996, pp. 2833). Using these categories, I was able to distinguish a limited number of recurring motifs that provided the basic elements for the different interpretations and opinions about the Cairo event. I concluded that the motifs all operated within very similar understandings of the meaning of the event and decided to call them shared story elements (SEs). ${ }^{3}$ Each story element consists of various notions and concepts and requires a certain degree of interpretation. For instance, the element "Obama as a master of soft power, changing global relations" includes positive notions about Obama's diplomatic efforts to negotiate peace in the Middle East, about his (stated or presumed) conviction to multilateralism, about his personal skills as an intercultural communicator, and about his favourable popular image among Muslims. I assumed that each of these notions contributed to a storyline in which Obama features as a change-maker in international politics and global relations, and so they could be dealt with together as a distinctive story element. 
TABLE 1. Shared story elements (SES) in the coverage of the Cairo address and number of articles containing each story element

\section{Story element}

\section{Main contexts of the event}

1. Intercultural relations

2. The Middle East conflict

Problem definitions

3. Problems of communication

4. Muslim political orientation and al-Qaeda

5. Israel's hard-line policies

6. Palestinian/Arab unwillingness for peace

7. The US foreign policies

Solutions

8. Cultural rapprochement

9. Muslims isolating extremists, embracing universal values

10. Change in Israeli policies

11. Change in Palestinian/Arab policies

12. Change in US (foreign) policies

\section{Perceived importance of the event}

13. Obama as different from Bush

14. Obama as a master of soft power, changing global relations

15. Obama as an impotent/partial actor

16. Obama continuing old US policies, interests
Typical notions in the coverage

$\mathbf{N}$

"The Muslim world" as the intended audience of the speech; 106 Antagonism between the West and the Muslims

The Israel-Palestine conflict; Stalled peace process in the 95 Middle East

Distrust, suspicion, misunderstandings, lack of dialogue, name- 42 calling, hate speech, fear

Unpopularity of the United States among Muslims; Lack of 52 democracy and violent extremism; al-Qaeda's popularity

Settlement expansion in the West Bank; Netanyahu rejecting 68 calls for settlement freeze and two-state solution

Palestinian violence; Lack of security guarantees for Israel

Historical support for Israel; Military presence in the Middle East; Wars in Iraq and Afghanistan; Support for totalitarian regimes; Political realism, national interests

Reconciliation, dialogue, mutual respect, tolerance, 66 overcoming suspicions and prejudices, common values and interests

Common fight against terrorism; Defeating al-Qaeda as path to peace; Muslim countries realising democracy, freedom of religion and opinion, respect of minorities

Settlement freeze; Two-state solution

End of violence; Guarantees for Israel's security; Normalising 30 relations with Israel

More even-handed approach to Israel/Palestine; Orchestrating 37 peace in the Middle East; End to Iraqi occupation and torture; Respect for international law and values

Honest, humble, respectful, peaceful, not arrogant; Tough on 54 Israel

Engaged to peace efforts; Committed to multilateralism; Skilful 69 intercultural communicator; Multicultural background; Favourable popular image among the Muslims

Muslims waiting for actions; Rhetoric not enough; Unable to 40 press Israel, achieve peace

No real change in policies; Continues realpolitik in the Middle 31 East 
After determining a limited number of story elements, I went through the material again, this time identifying the articles in which each element occurred in the newspapers (see Table 1). ${ }^{4}$ It should be noted that the number of articles containing a specific story element does not indicate anything about the relative weight of the elements within an article. Concerning the Israeli-Palestinian conflict, for example, many articles focused on the issue of the Israeli settlement construction in the West Bank and only briefly acknowledged Israel's stated need for security guarantees. Still, both of these story elements were coded as being equally present (once) in that particular article. However, as this analysis is qualitative in nature, I did not see it as necessary to develop a more sophisticated method of weighing the presence of different elements in an article. Even without such arithmetic it became clear that while there were elements for several different interpretations present in the overall coverage*and the newspapers thus offered a polyphonic account of the speech*the elements emphasised over others were the same in each paper. In this sense the studied newspapers ended up constructing a rather unified overall account from the Cairo event as the next section demonstrates.

\section{Constructing a Shared Narrative}

Based on the recurrent concepts and themes across the two-week period, two main journalistic interpretations about President Obama's speech in Cairo emerge from the coverage. The first concerns the intercultural relations between the West and the Muslim world. The second is about the Middle East conflict.

\section{Overcoming Cultural Divides}

As the repeated references in the coverage to "the Muslim world" suggest, the Cairo event is largely narrated in terms of transnational cultural relations (SE 1). In this storyline, President Obama tries to mend relations with the Muslim world and persuade Muslims to see a new era in which the United States is not their enemy. The necessity of such an effort is based, naturally, on the premise that the United States has damaged ties with this religious community. Alternatively, the rift is perceived to exist between two civilisations, the West and Islam. On one level, then, the Cairo speech as a news event addresses this perceived conflict between cultures and is represented in cultural terms.

A common way to characterise the intercultural conflict is that the problem lies in mutual distrust, suspicion, misunderstandings, incomprehension and lack of dialogue (SE 3). This can be seen as the Obama Administration's preferred framing of the event. Obama is quoted as saying that his goal is "to overcome misunderstandings", and in the address he laments how hard it is to overcome "decades of distrust". Following the same culturalist argument, the presumed solutions to the problems lie in reconciliation, dialogue, respect, tolerance and common values (SE 8). These communicative definitions of the problem and its solutions are widely picked up by all the studied newspapers and feature in approximately one-third of all the articles.

However, while the President talks about common values and interests he also presupposes a fundamental cultural division by addressing Muslims as a unified whole. This makes him vulnerable to a counter-narrative based on the same premise. Just before Obama's arrival in Cairo, the al-Qaeda front men Ayman al-Zawahiri and Osama bin Laden have denounced the US policies in separate tape recordings and warned the Muslim community of Obama's "deceitful message". These interventions work as reminders of the challenge Obama faces in the region: al-Qaeda derives its influence from the deep unpopularity of America felt by many in the Muslim world. With the introduction of al-Qaeda, 
the newspaper coverage tunes into the struggle over the popular sentiments among ordinary Muslims and their political and ideological orientation with the West (SE 4). Obama needs to persuade Muslims to embrace the liberal values and to isolate the "violent extremists" (SE 9).

\section{Obstacles to Peace}

President Obama's task of winning the "hearts and minds" of Muslims becomes more complicated when connected to the other central context of the Cairo event. In contrast with the cultural narrative, the Middle East conflict storyline (SE 2) speaks in the realist geopolitical language of security, interests, policies, diplomacy and negotiations. The focus on the Israeli-Palestinian issue prompts journalists and columnists to assess the immediate reasons that prolong the conflict and impede peace negotiations: the continuing expansion of Israeli settlements in the West Bank (SE 5), and the lack of "solid security guarantees" for Israel in the region (SE 6). Consequently, a lasting peace is achievable only when the Israeli government accepts the premise of the two-state solution in Israel-Palestine, when the Palestinian Authority proves its capacity to guarantee security within its territory, and when the Arab states show readiness to open commercial and diplomatic relations with Israel (SEs 10 and 11).

Despite this general acknowledgement of the complexity of the conflict, the Netanyahu government and the US policies emerge as the principal obstacles to peace. While the Israeli argument on its lack of security guarantees is recognised (SEs 6 and 11), far more attention is given to the fact that Prime Minister Netanyahu continues to reject the US calls for a complete settlement freeze and to Israel's unwillingness to accept a two-state solution and cede territories in the West Bank (SEs 5 and 10). On the other hand, the United States is responsible for the deadlock, being the one player that can move Israel's position towards peace. In this regard, it is the historical US policy of unconditional support for Israel that becomes the main problem (SE 7). The US foreign policy also ties the two storylines of intercultural relations and the Middle East conflict together. In these accounts, the US's support for Israel not only hampers the peace process but also the cultural relations between America and the Muslim world. The plight of the Palestinian people is understood to have a strong importance for Muslims, and so the manner in which the United States addresses the Israel-Palestine conflict is seen as having great impact on how the global Muslim community regards the US government.

Moreover, the perceived pro-Israeli bias features as a major, but by no means the only, aspect of US foreign policy that turns the Muslim populations against the Americans (SE 7). The US military presence in the Middle East, its support for totalitarian regimes, and the double standards used with respect to the region and its problems are other repeatedly appearing explanations for the political and cultural rift between the United States and the Muslim world. According to this interpretation, the root of the problem lies in the American tradition of "political realism", which prefers stability to democratisation in the Middle East, and in "national interests", which, rather than any high ideals, ultimately dictate American foreign policy. Thus, achieving peace and stability in the Middle East and real improvement in the intercultural relations would require a concrete change in US foreign policy and its underlying paradigms (SE 12).

\section{Does a President Make a Difference?}

Against this background of long-term foreign policies and national interests, how do journalists and analysts make sense of the Cairo speech and its significance? What makes it possible to hope for an improvement in intercultural relations and peace in the Middle East? This is where the figure of President Obama comes in. In the common storyline, Obama arrives in Cairo as a peacemaker who 
invites the Islamic countries to a dialogue. He represents a new style of leadership, which is characterised as being honest, humble, respectful, peaceful and not arrogant. Perhaps most importantly, Obama represents a break with the Bush era and has taken a firmer attitude than his predecessor in dealings with Israel (SE 13). In addition, his personal background, cultural sensitivity and skills as communicator are seen as important assets in the task of overcoming the conflict between the West and the Muslim world. With him, Muslims' attitudes toward the United States are believed to have changed for the better (SE 14).

Thus in the more positive interpretations (SEs 13 and 14) about the Cairo event, President Obama's political beliefs and cultural assets gain great significance and an improvement in intercultural relations can lead to political changes in the Middle East. In this regard, the speech has the potential of becoming a historically significant event. The Cairo address is a masterful display of soft power, persuasion, dialogue and moral example, and it marks a turning point in global relations, substituting unilateralism with co-operation and understanding.

Yet the celebration of President Obama's communicative skills is balanced by a sense of political reality. Muslims wait to see whether the President's fine words and stated convictions are followed by concrete actions. This, however, is proving to be difficult. Journalists see Obama as unable to force the unwilling Israeli government to the peace table ultimately because of the power of the Israeli lobby in America and the lack of domestic political support for such a policy that would mean severing "unbreakable ties" with Israel. Hence, there is no real evidence that shows Obama is succeeding in moving the Middle East peace process forward (SE 15).

Some authors also point to Obama's political inability to adhere to the values he preaches. While emphasising the importance of international law, for example, Obama is under domestic pressure to continue the unlawful treatment of Guantánamo prisoners. The necessity to support the authoritarian regimes of Egypt and Saudi Arabia is undermining his message of democratisation and respect for human rights. As even the wars in Iraq and Afghanistan still continue, it is suddenly difficult, from the point of view of actual foreign policy, to make a distinction between presidents Obama and Bush. Consequently, the idea that Obama would represent a break in US policies and bring about a new era of multilateralism lacks evidence (SE 16).

In the journalistic accounts, then, the two main problems with respect to the Middle East conflict and the intercultural relations between the West and the Muslim world are Israel and its hard-line policies, and the United States and its policies of national interest. These come in the way of achieving the stated objectives of reconciliation and peace and of realising the common values of democracy and human rights. This leads to the need to see a change in Washington, a change that is based on the liberal values of multilateral diplomacy, intercultural dialogue, democracy and respect of universal human rights. Obama's stated belief in these values, as well as his tough public stance in relation to Israel, is considered to give cause for optimism. However, the uncertainty and lack of any concrete changes in US foreign policy cast a shadow of doubt on Obama's rhetoric and puts the promise of change into question.

\section{European Imaginary of Global Relations}

To examine the construction of global imaginary in the coverage of the Cairo event I draw on Berglez's (2008) ideas about global journalism as a way to recognise the representation of the transnational interconnectedness of social reality in news reporting. While traditional foreign news journalism 
concentrates on one spatial, political or cultural context, global journalism connects peoples, places and actions across borders and regions. Essentially, global journalism concerns the representation of complex relations, as "relations comprise a fundamental cognitive category" (Berglez, 2008, p. 848). These relations can exist between organisations, institutions, nations and identities, and they can be presented as historical or contemporary. Accordingly, when analysing journalistic texts, Berglez (2008, p. 849) suggests drawing attention particularly to the ways spatial relations, power relations and identity relations are represented to construct an image of an interconnected world.

Following Berglez's ideas, the coverage of the Cairo address can be examined as a representation of multiple spaces, powers and identities as summarised in Table $2 .{ }^{5}$ Firstly, the newspaper correspondents in Cairo interview the locals, describe the security measures and other preparations to Obama's visit and speculate its impact on the national political scene. Secondly, being closely tied to the Middle East conflict, the event becomes part of an international space, which is perceived as a playing arena for various actors and extends as a political space to places and powers outside the geographic limits of the region. Finally, the event's scenery involves the cultural spaces and collective identities of "the West" and "the Muslim world". With the representations of these imagined communities, the perceived political and geographic landscape becomes one of transnational cultural relations.

TABLE 2. Representations of space, power and identities in the news coverage of the Cairo address (adapted from Berglez, 2008, p. 854)

\begin{tabular}{|c|c|}
\hline \multicolumn{2}{|l|}{ Space } \\
\hline Local/national space & Cairo and Egypt \\
\hline International space & The Middle East, the United States \\
\hline Transnational space & The Muslim world and the West \\
\hline \multicolumn{2}{|l|}{ Power } \\
\hline Local/national actors & The Mubarak regime, the opposition, the Muslim Brotherhood \\
\hline International actors & The political leaders of the Middle East and the United States \\
\hline Transnational actors & President Obama, al-Qaeda \\
\hline \multicolumn{2}{|l|}{ Identities } \\
\hline Local/national identities & Cairo resident, Egyptian citizen \\
\hline Transnational identities & The Muslim public, the West \\
\hline
\end{tabular}

The notion of global journalism draws attention to the ways the journalistic accounts define the news event in terms of geopolitical relations and intercultural struggles. In this way, global journalism may be understood as participating in the construction of a particular social imaginary in which the political space is imagined in a non-state-centric manner. In the studied Western European newspapers, the Cairo event is evaluated within a mental map in which the world is understood not as an international system based solely on nation-states. Instead, the context is perceived as a multi-level and complex field in which local, national and transnational spaces, events and actors interact with one another and in which wide-ranging cultural spheres organise and give meaning to the actions of individuals and groups.

In these accounts, nation-states remain as central power-holders and definers of collective fortunes. At the same time, states need to operate with new kinds of transnational actors whose agency does not 
derive from their nationality and whose influence is potentially global. In the journalistic accounts of the Cairo event, al-Qaeda, with its message of the global struggle against the colonialist policies of the West and the oppressive regimes of many Muslim countries, is one such transnational actor. However, the Islamist network is confronted by another transnational agent, lecturing about peace, democracy, human rights, freedom of religion and gender equality, and presenting them as common values of both "the West" and "the Muslims". President Obama, then, becomes more than a national figure and qualifies as a global leader.

If these are the common terms with which the newspapers construct global imaginary, what role do the political and national differences play in the coverage? The metanarrative outlined above is not meant to imply that the studied newspapers presented the Cairo event in exactly the same way or that only one interpretation of the event circulated in the papers at the time. Due to the qualitative nature of the analysis the following observations need to be addressed with considerable caution, but it is fairly safe to argue that, while all the papers offered space for differing points of view, some of the shared story elements featured more prominently in some newspapers than in others (see Table 3 ). President Obama's approach to the conflict between Israel and Palestine seems to get more attention in The Independent and The Times, which shows in the slightly higher number of times the conflict appears as a story element (SEs 5, 6, 10 and 11) in the British newspapers than in others. Moreover, arguments about US foreign policy as a source of intercultural frictions and political instability in the Middle East (SEs 7 and 12 ) receive slightly more attention in the traditionally left-leaning papers (The Independent, El País, Süddeutsche Zeitung) than in their more conservative counterparts. Despite some differences in tone, however, a generally critical attitude towards the policies of both Israel and the United States is dominant in all the papers.

Consequently, the main differences between the newspapers emerge not in the way the Middle East politics and intercultural relations are understood but in the manner in which the significance of the Cairo event is perceived. Doubts about Obama's intentions and ability to negotiate peace (SE 15) are particularly strongly present in The Independent, while El País gives relative emphasis on the more sympathetic account of Obama as the change-maker in global politics (SE 14). However, while all the papers express doubts about Obama, overall the favourable accounts about the new President as peacemaker and a welcome change to the Bush era gain more momentum than their respective counter-narratives, with The Independent offering the most balanced coverage in this sense. To sum up, there were surprisingly few signs of political or ideological differences between the newspapers. All manifested generally positive attitudes toward Obama yet critical perspectives on the United States and Israel. The papers also shared a very similar understanding about the responsible agents in the conflicts. There were, for instance, no demands for the European Union to engage in intercultural dialogue, and only few attempts to stress the responsibility of Muslims or the Arab states in the Middle East conflict. 
TABLE 3. The number of articles containing shared story elements (SEs) in each newspaper

\section{Story element}

Main contexts of the event

1) Intercultural relations

2) The Middle East conflict

$\begin{array}{llllll}\text { ABC } & \text { EP } & \text { FAZ } & \text { SZ } & \text { TI } & \text { TT } \\ & & & & & \\ 26 & 14 & 15 & 20 & 15 & 16 \\ 17 & 15 & 16 & 17 & 16 & 14\end{array}$

Problem definitions

3) Distrust, misunderstandings, lack of dialogue

$\begin{array}{llllll}3 & 7 & 7 & 9 & 7 & 9\end{array}$

4) Muslim political orientation, violent extremism

$\begin{array}{llllll}10 & 9 & 7 & 10 & 8 & 8\end{array}$

5) Israel's hard-line policies, settlement construction

$\begin{array}{llllll}8 & 12 & 12 & 11 & 11 & 14\end{array}$

6) Palestinian violence, Arab unwillingness for peace

7) The US foreign policies, support for Israel

$\begin{array}{llllll}2 & 4 & 1 & 3 & 5 & 3\end{array}$

$\begin{array}{llllll}9 & 8 & 7 & 9 & 10 & 6\end{array}$

Solutions

8) Reconciliation, common values, dialogue

9) Muslims isolating extremists, embracing universal values

$\begin{array}{llllll}16 & 9 & 11 & 12 & 8 & 10\end{array}$

10) Israel agreeing to settlement freeze, two-state solution

$\begin{array}{llllll}7 & 2 & 2 & 4 & 2 & 3\end{array}$

11) Arabs guaranteeing security for Israel, normalizing relations

12) Change in US foreign policies

$\begin{array}{llllll}9 & 10 & 10 & 12 & 15 & 16\end{array}$

$\begin{array}{llllll}5 & 8 & 5 & 2 & 6 & 4\end{array}$

$\begin{array}{llllll}7 & 6 & 5 & 6 & 7 & 6\end{array}$

Perceived importance of the event

13) Obama different from Bush, tough on Israel

$\begin{array}{llllll}9 & 11 & 7 & 7 & 10 & 10\end{array}$

14) Obama master of soft power, changing global relations

15) Obama impotent/partial actor, rhetoric not enough

$\begin{array}{llllll}11 & 16 & 10 & 12 & 10 & 10\end{array}$

16) Obama continuing old US policies, interests

$\begin{array}{llllll}9 & 4 & 4 & 7 & 10 & 6\end{array}$

Total number of articles

$\begin{array}{llllll}6 & 5 & 5 & 4 & 6 & 5\end{array}$

$\begin{array}{llllll}33 & 20 & 25 & 27 & 22 & 23\end{array}$

EP, EIPaís; FAZ, Frankfurter Allgemeine Zeitung; SZ, Süddeutsche Zeitung;

$\mathrm{TI}$, The Independent; TT, The Times.

There were some indications of domestication in the material. Perhaps predictably, President Obama's visit to Germany directly after the Cairo speech and his meeting with Chancellor Merkel were covered by the German press more extensively than in other newspapers analysed. In the Spanish coverage, both EI País, and especially $A B C$, concentrated on particular parts of Obama's address that made direct references to Spanish history and recent foreign policy initiatives of the Spanish Prime Minister. Another instance of domestication occurred in The Times when Tony Blair's capacity as special envoy to the Middle East was highlighted in a column. These obvious instances of domestication played, however, only a marginal role in the material: there were no signs of a national point of view in the central narratives of the Middle East conflict or the intercultural relations. This may be explained by the fact that none of the countries from which the material was collected was directly involved in the news event. For the Western European press, then, the Cairo speech was a very specific case of global news that came without any immediate national perspective. Presumably, domestication played a significantly greater role, for instance, in the American, Israeli and Egyptian newspaper coverage of the same event.

In a sense, the congruence found in the Western European newspaper coverage is not a surprising discovery. Several studies have observed the emergence and strengthening of a transnational news agenda resulting from structural and professional developments in news media and journalistic 
practices. The 24-hour news networks, international news agencies, transnational ownership of the news media as well as journalists' transnational networks of newsgathering and their growing professionalisation have all contributed to the formation of a global news arena in which the same issues and talking points circulate worldwide (Boyd-Barrett and Rantanen, 1998; Clausen, 2003; Löffelholz and Weaver, 2008; Riegert, 2010). The common news agendas emerge out of a shared understanding in newsrooms over the available news items in the global news arena (Hjarvard, 2001, pp. 323; Reese, 2008).

In this case, the newsrooms of the six Western European newspapers clearly made decisions in unison over the importance of the Cairo event and the main issues to which it was connected. The absence of obvious national interests in the event and the careful pre-scripting of the speech by the Obama Administration probably explains the common framing of the event around the two general storylines of intercultural relations and the Middle East conflict, as well as the repetition of some of the key concepts in the coverage. However, the US administration could not control the storyline about President Obama himself and about US foreign policy. These became the central elements in the normative account that, partly, turned against the President. While Obama's high popularity in Europe after his election can be evidenced in the generally favourable accounts of his character, the quality European newspapers already offered critical and sceptical interpretations on his foreign policy agenda in June 2009.

The common storyline of the British, German and Spanish newspapers about President Obama's speech clearly develops global imaginary in the sense of drawing transnational connections between spaces, powers and identities. At the same time the newspapers, regardless of their political leanings, seem to mediate and construct a rather unified narrative. ${ }^{6}$ The shared European view of the Middle East emphasises such ideals as peace, democracy, intercultural dialogue and multilateralism, which are then used to evaluate the conduct of the central parties in the conflict. As Ernesto Laclau (1996) has pointed out, Western Eurocentrism has a long history of posing the values it purports to represent as universal, despite them being inevitably tied to a particular context. Following Laclau's argument, the observed congruence of the Western European accounts of the Cairo event tells us, firstly, that the construction of global imaginary involves the presentation of certain principles as universally valid, and secondly, that the imaginary of an interconnected world is always constructed from a particular cultural and ideological perspective. In the European narrative of the Middle East and the intercultural relations, the United States and Israel are made to bear the greatest responsibility of adhering to the "universal" values.

\section{Conclusion}

The purpose of this article has been to investigate how journalism constructs global imaginary in a transnational news event. I have pursued this by connecting the concept of global imaginary with Berglez's (2008) ideas of global journalism as a reporting style that displays transnational links between events and phenomena. The analysis indicates that the quality European press tends to construct a rather unified understanding of the Middle East conflict, US foreign policy and the intercultural relations between "the West" and "the Muslim world". However, the analysed material was small and case-specific, which makes any generalisations highly speculative. Whether the material demonstrates a characteristically Western European narrative on the Cairo event should be further examined by a comparison with the coverage of the same event in other countries and regions. Additionally, the analysis operated on a rather superficial textual level of political commentary and did not address deeper cultural frames or structures of meaning embedded in journalism. Examining the 
more profound level of cultural frames and discourses might have uncovered both national and ideological differences that are now left unexposed.

These caveats notwithstanding, the analysis of global journalism draws attention to the ways in which journalists situate transnational news events into particular contexts and frameworks. It is a practice that involves the construction of a social imaginary in which social relations are perceived on a transnational scale. For Berglez $(2007,2008)$, the notion of global journalism serves as a normative ideal: demonstrating the interrelatedness of actions, processes and phenomena "the global journalist" potentially fosters the public recognition of global interdependency. Various constraints in the actual production of news make this ideal hard to achieve. Drawing transnational connections between localities, actors and events is often a laborious and time-consuming intellectual exercise in which reporters seldom have the luxury to engage. In addition, the public agenda is usually dominated by local and national concerns, which leaves little room for transnational issues. Hence Berglez sees global journalism as operating in the margins of news.

However, if we understand global journalism as being part of the more general transformation of political imaginary, the situation looks different. With the rise of the global imaginary (i.e. the growing emphasis on transnational issues in public life) it is natural for journalism, too, to adopt broader frames of reference. At the same time, while global journalism as a news style may be seen as a way of adopting more comprehensive interpretive frameworks in news reporting and even endorsed for fostering global awareness, it is also problematic to regard the cultural construction of global imaginary as an intrinsically desirable phenomenon. The analysis indicates how the imaginary of global relations constructed by the newspapers is a particular normative interpretation of the relations between localities, powers and identities. As indicated in Steger's (2009) historical analysis of the competing globalist ideologies, global imaginary is always drawn from a particular cultural and ideological perspective. The image of an interconnected world, then, does not necessarily entail a liberal world-view or support for a multicultural society, and it should not be equated to the notion of cosmopolitanism. Similarly, global journalism should be regarded not as a normative ideal but as mediation of the global imaginary, which always contains particular globalist discourses.

\section{Notes}

1. Video and transcript of the speech is available at the White House website: http://www. whitehouse.gov/the-press-office/remarks-president-cairo-university-6-04-09 (accessed 24 April 2011).

2. Only those online articles, which did not appear in the print version of the newspaper, were included in the material. Overall, 41 out of the 150 analysed articles were published online only.

3. The uncovered story elements have some similarities with the frames in frames analysis, when frames are understood as promoting a particular problem definition, causal interpretation, moral evaluation and treatment recommendation (Entman, 1993, p. 52). However, whereas the concept of a frame refers to latent meaning structures and broad cultural discourses (Reese, 2007; Van Gorp, 2007), what I call the story elements in this analysis operate on a rather manifest and more precise level of description and argumentation. In this sense, the two general storylines found in the material*the Middle East conflict and the cultural conflict between the West and the Muslim world* could perhaps be called frames, and the rest of the story elements could be seen as the particular claims and interpretations made within those frames (i.e. arguments for instance about the US or Israel policies being the primary causes for the current conflicts). In this case study I concentrated more on the level of explicit arguments and less on the latent and partly unconscious level of framing.

4. Not all issues and themes in the coverage could be included within these story elements. For instance, some reports about Cairo preparing for Obama's visit, descriptions of the Egyptian national political situation, or accounts of the talks between Obama and Chancellor Merkel, did not fit the two main storylines about the intercultural relations and the Middle East conflict. 
5. While Berglez focuses on individual news articles as examples of global journalism, in this case I address the coverage of the Cairo speech in each of the analysed newspapers as a whole.

6. This common European narrative may be interpreted as a counterpart to the shared perspective of the IsraeliPalestinian conflict found in the US press (Zelizer et al., 2002; see also Goldfarb, 2001).

\section{References}

ALBROW, MARTIN (1996) The Global Age: state and society beyond modernity, Cambridge: Polity Press.

ALTHEIDE, DAVID L. (1996) Qualitative Media Analysis, Thousand Oaks, CA: Sage.

ANDERSON, BENEDICT (1991) Imagined Communities, London: Verso.

BERGLEZ, PETER (2007) "For a Transnational Mode of Journalistic Writing", in: Birgitta Höijer (Ed.), Ideological Horizons in Media and Citizen Discourses, Gothenburg: Nordicom, pp. 14761.

BERGLEZ, PETER (2008) “What Is Global Journalism?”, Journalism Studies 9(6), pp. 845-58.

BILTEREYST, DANIEL (2001) “Global News Research and Complex Citizenship: towards an agenda for research on foreign/international news and audiences", in: Stig Hjarvard (Ed.), News in a Globalized Society, Gothenburg: Nordicom, pp. 41-62.

BOYD-BARRETT, OLIVER and RANTANEN, TERHI (Eds) (1998) The Globalization of News, London: Sage.

CAMERON, ANGUS and PALAN, RONEN (2004) The Imagined Economies of Globalization, London: Sage.

CLAUSEN, LISBETH (2003) Global News Production, Copenhagen: Copenhagen Business School.

COTTLE, SIMON (2009) "Global Crises in the News: staging new wars, disasters and climate change", International Journal of Communication 3, pp. 494-516.

EIDE, ELISABETH, KUNELIUS, RISTO and PHILLIPS, ANGELA (2008) “Contrapuntal Readings: transnational media research and the cartoon controversy as a global news event", in: Elisabeth Eide, Risto Kunelius and Angela Phillips (Eds), Transnational Media Events: the Mohammed cartoons and the imagined clash of civilizations, Gothenburg: Nordicom, pp. 11-27.

ENTMAN, ROBERT M. (1993) "Framing: toward clarification of a fractured paradigm", Journal of Communication 43(4), pp. 5-18.

FAIRCLOUGH, NORMAN (2006) Language and Globalization, London: Routledge.

GAONKAR, DILIP P. (2002) “Toward New Imaginaries: an introduction”, Public Culture 14(1), pp. 1-19.

GOLDFARB, MICHAEL (2001) “All Journalism Is Local: reporting on the Middle East", The Harvard International Journal of Press/Politics 6(3), pp. 110-5.

GUREVITCH, MICHAEL, LEVY, MARK R. and ROEH, ITZHAK (1993) "The Global Newsroom: convergences and diversities in the globalization of television news", in: Peter Dahlgren and Colin Sparks (Eds), Communication and Citizenship: journalism and the public sphere, London: Routledge, pp. 195-215.

HALLIN, DANIEL C. and MANCINI, PAOLO (1994) "Summits and the Constitution of an International Public Sphere: the ReaganGorbachev meetings as televised media events", in: Daniel C. Hallin (Ed.), We Keep America on Top of the World: television journalism and the public sphere, London: Routledge, pp. 136-51.

HANNERZ, ULF (2004) Foreign News: exploring the world of foreign correspondents, Chicago: University of Chicago Press.

HEIKKILÄ, HEIKKI and KUNELIUS, RISTO (2008) “Ambivalent Ambassadors and Realistic Reporters: the calling of cosmopolitanism and the seduction of the secular in EU journalism", Journalism 9(4), pp. 377-97.

HJARVARD, STIG (2001) "News Media and the Globalization of the Public Sphere", in: Stig Hjarvard (Ed.), News in a Globalized Society, Gothenburg: Nordicom, pp. 17-39.

KANTOLA, ANU (2007) "On the Dark Side of Democracy: the global imaginary of financial journalism", in: Bart Cammaerts and Nico Carpentier (Eds), Reclaiming the Media: communication rights and democratic media roles, Bristol: Intellect, pp. 192-216.

KELLNER, DOUGLAS (2010) “Celebrity Diplomacy, Spectacle and Barack Obama”, Celebrity Studies 1(1), p. 121 $A B$. 
LACLAU, ERNESTO (1996) Emancipation(s), London: Verso.

LÖFFELHOLZ, MARTIN and WEAVER, DAVID H. (Eds) (2008) Global Journalism Research: theories, methods, findings, future, Oxford: Wiley-Blackwell.

MARSHALL, P. DAVID (1997) Celebrity and Power: fame in contemporary culture, Minneapolis:

University of Minnesota Press.

MAYRING, PHILIPP (2000) "Qualitative Content Analysis", Forum: Qualitative Social Research 1(2), http://nbnresolving.de/urn:nbn:de:0114-fqs0002204, accessed 23 April 2011.

REDMOND, SEAN (2010) "Avatar Obama in the Age of Liquid Celebrity”, Celebrity Studies 1(1), pp. 81-95.

REESE, STEPHEN D. (2007) "The Framing Project: a bridging model for media research revisited", Journal of Communication 57(1), pp. 148-54.

REESE, STEPHEN D. (2008) “Theorizing a Globalized Journalism”, in: Martin Löffelholz and David H. Weaver (Eds), Global Journalism Research: theories, methods, findings, future, Oxford: Wiley Blackwell, pp. 240-52.

RIEGERT, KRISTINA (2010) "National Television News of the World: challenges and consequences", in: Anna Roosvall and Inka Salovaara-Moring (Eds), Communicating the Nation: national topographies of global media landscapes, Gothenburg: Nordicom, pp. 195-213.

ROBERTSON, ALEXA (2005) "Journalists, Narratives of European Enlargement, and the Man-on-the-Sofa", Statsvetenskaplig Tidskrift 107(3), pp. 235-57.

ROBERTSON, ROLAND (1992) Globalization: social theory and global culture, London: Sage.

ROOSVALL, ANNA (2010) "Image-nation: the national, the cultural and the global in foreign news slide-shows", in: Anna Roosvall and Inka Salovaara-Moring (Eds), Communicating the Nation: national topographies of global media landscapes, Gothenburg: Nordicom, pp. 215-36.

SAUKKO, PAULA (2003) Doing Research in Cultural Studies, London: Sage.

SCHUDSON, MICHAEL (2003) The Sociology of News, New York: W. W. Norton.

SLAATTA, TORE (2001) "Transnational Politics and News Production: Norwegian correspondents on the Brussels beat", in: Stig Hjarvard (Ed.), News in a Globalized Society, Gothenburg: Nordicom, pp. 129-47.

STEGER, MANFRED B. (2009) The Rise of the Global Imaginary, Oxford: Oxford University Press.

TAYLOR, CHARLES (2002) “Modern Social Imaginaries”, Public Culture 14(1), pp. 91-124.

VAN GORP, BALDWIN (2007) "The Constructionist Approach to Framing: bringing culture back in", Journal of Communication 57(1), pp. 60-78.

ZELIZER, BARBIE, PARK, DAVID and GUDELUNAS, DAVID (2002) “How Bias Shapes the News”, Journalism 3(3), pp. 283-307. 